\title{
Potassium Ferrate (VI) as the Multifunctional Agent in the Treatment of Landfill Leachate
}

\author{
Maciej Thomas ${ }^{1, *} \mathbb{B}$, Violetta Kozik ${ }^{2, *}$, Krzysztof Barbusiński $^{3}$, Aleksander Sochanik ${ }^{4}$, \\ Josef Jampilek ${ }^{5}$ (D) and Andrzej Bąk ${ }^{2}$ (D) \\ 1 Chemiqua Water\&Wastewater Company, Skawińska 25/1, 31-066 Kraków, Poland \\ 2 Institute of Chemistry, University of Silesia, Szkolna 9, 40-007 Katowice, Poland; andrzej.bak@us.edu.pl \\ 3 Department of Water and Wastewater Engineering, Silesian University of Technology, Konarskiego 18, \\ 44-100 Gliwice, Poland; krzysztof.barbusinski@polsl.pl \\ 4 Center for Translational Research and Molecular Biology of Cancer, Maria Skłodowska-Curie Memorial \\ Cancer Center and Institute of Oncology, Wybrzeże AK 15, 44-101 Gliwice, Poland; \\ aleksander.sochanik@io.gliwice.pl \\ 5 Department of Analytical Chemistry, Faculty of Natural Sciences, Comenius University, Ilkovicova 6, \\ 84215 Bratislava, Slovakia; josef.jampilek@gmail.com \\ * Correspondence: biuro@chemiqua.pl (M.T.); violetta.kozik@us.edu.pl (V.K.); Tel.: +48-032-359-1336 (V.K.)
}

Received: 5 October 2020; Accepted: 4 November 2020; Published: 6 November 2020

check for updates

\begin{abstract}
Possible use of potassium ferrate (VI) $\left(\mathrm{K}_{2} \mathrm{FeO}_{4}\right)$ for the treatment of landfill leachate ( $\mathrm{pH}=8.9$, Chemical Oxygen Demand (COD) $770 \mathrm{mg} \mathrm{O}_{2} / \mathrm{L}$, Total Organic Carbon (TOC) $230 \mathrm{mg} / \mathrm{L}$, Total Nitrogen (Total N) $120 \mathrm{mg} / \mathrm{L}$, Total Phosphorus (Total P) $12 \mathrm{mg} / \mathrm{L}$, Total Coli Count (TCC) $6.8 \log \mathrm{CFU} / \mathrm{mL}$ (Colony-Forming Unit/mL), Most Probable Number (MPN) of fecal enterococci $4.0 \mathrm{log} / 100 \mathrm{~mL}$, Total Proteolytic Count (TPC) $4.4 \log$ CFU/mL) to remove COD was investigated. Central Composite Design (CCD) and Response Surface Methodology (RSM) were applied for modelling and optimizing the purification process. Conformity of experimental and predicted data $\left(R^{2}=0.8477, R_{\mathrm{adj}}{ }^{2}=0.7462\right)$ were verified using Analysis of Variance (ANOVA). Application of $\mathrm{K}_{2} \mathrm{FeO}_{4}$ using CCD/RSM allowed to decrease COD, TOC, Total N, Total P, TCC, MPN of fecal enterococci and TPC by $76.2 \%, 82.6 \%, 68.3 \%, 91.6 \%, 99.0 \%, 95.8 \%$ and $99.3 \%$, respectively, by using $\mathrm{K}_{2} \mathrm{FeO}_{4} 0.390 \mathrm{~g} / \mathrm{L}$, at $\mathrm{pH}=2.3$ within $25 \mathrm{~min}$. Application of equivalent amount of iron (as $\mathrm{FeSO}_{4} \times$ $7 \mathrm{H}_{2} \mathrm{O}$ and $\mathrm{FeCl}_{3} \times 6 \mathrm{H}_{2} \mathrm{O}$ ) under the same conditions allowed to diminish COD, TOC, Total N, Total $\mathrm{P}$, TCC, MPN of fecal enterococci and TPC only by 38.1\%, 37.0\%, 20.8\%, 95.8\%, 94.4\%, 58.2\%, 90.8\% and $41.6 \%, 45.7 \%, 29.2 \%, 95.8 \%, 92.1 \%, 58.2 \%, 90.0 \%$, respectively. Thus, $\mathrm{K}_{2} \mathrm{FeO}_{4}$ could be applied as an environmentally friendly reagent for landfill leachate treatment.
\end{abstract}

Keywords: landfill leachate; response surface methodology; central composite design; potassium ferrate (VI)

\section{Introduction}

Several aspects of human agricultural and industrial activity are related to adverse changes in the quality of water resources worldwide. Undoubtedly, such activity has a direct impact on the waste production. In fact, some waste undergoes various disposal processes while other is deposited in municipal landfills. As a result of the municipal waste landfills exploitation, leachate is generated. In case of insufficient protection, it may get into the soil or groundwater and, due to its physicochemical and microbiological composition, this may significantly contribute to the groundwater contamination. The amount of leachate and their characteristics depend on a number of factors, including: type of waste, degree of fragmentation, compaction and storage method, landform, amount of precipitation, method of sealing the bottom of the landfill, type of vegetation covering the landfill, soil conditions, 
etc. [1]. It is widely known that the values of parameters (e.g., COD, TOC etc.) for the landfill leachate were higher in the dry season than in the rainy season for the fresh leachate samples. Recent research points to a higher content of heavy metals in the suspensions. Moreover, there were no significant seasonal changes in the concentration of heavy metal ions in suspended solids and sediment samples [2].

Nevertheless, depending on the age of the landfill (young $<5$ years; medium 5-10 years; old $>10$ years), the physicochemical composition of the leachate may vary [3,4]. According to the available data [4-12], the $\mathrm{pH}$-value of the leachate varies in the range of 4-7.6, 6.9-9 and 8.1-9.5 for the leachate from young, medium and old landfills, respectively. In the case of COD and TOC, a decrease in the values of these indicators was observed according to the age of the landfills, and for COD they amounted to approx. 1.87-84.30, 0.56-9.50 and 0.10-3.46 $\mathrm{g} \mathrm{O}_{2} / \mathrm{L}[4,13-16]$, and for TOC approx. $1.60-13.61 \mathrm{~g} / \mathrm{L}, 0.19-2.05 \mathrm{~g} / \mathrm{L}$ and $0.04-1.90 \mathrm{~g} / \mathrm{L}$ [16-23]. Similar dependencies were observed in the case of total nitrogen (approx. 1.75-4.37, 0.35-3.00 and 0.42-2.64 g/L) and total phosphorus (approx. 2-655, 3-18 and 1-7 mg/L) [18,24-31]. Municipal landfills effluents may also contain small amounts of heavy metals such as: $\mathrm{Cd}(<0.02-6.5 \mathrm{mg} / \mathrm{L}), \mathrm{Cu}(0.005-6 \mathrm{mg} / \mathrm{L}), \mathrm{Pb}(0.01-3.50 \mathrm{mg} / \mathrm{L})$, and even $\mathrm{Cr}^{6+}$ $(0.04-8.4 \mathrm{mg} / \mathrm{L})[4,31-34]$.

Due to the fact that the leachate from municipal landfills comprises a significant amount of organic compounds and shows significant physicochemical parameters variation depending on their age, they create many technical and technological problems during their treatment. For this reason, various physicochemical and biological methods are used to treat the leachate. The landfill leachate could be treated with: ozone after coagulation treatment [7], ozonation [21], hydrodynamic cavitation [11], catalytic oxidation (by using $\mathrm{Ni} / \mathrm{Al}_{2} \mathrm{O}_{3}$ as the catalyst) by supercritical water oxidation [12], coagulation-flocculation, chemical coagulation and reverse osmosis system [13,30], hybrid coagulation-nanofiltration process [20], electrocoagulation [15], electrochemical oxidation [17], photoelectrochemical treatment in a continuous flow reactor [16], coagulation and Fenton reagent, UV, $\mathrm{H}_{2} \mathrm{O}_{2}$ and $\mathrm{UV} / \mathrm{H}_{2} \mathrm{O}_{2}$ process [35-37].

The presented physicochemical methods require the use of physical factors (e.g., pressure, electric current etc.), various chemical compounds (coagulants, catalysts, etc.) devices and conditions in order to obtain high purification efficiency. Not all of these methods have found practical application due to, sophisticated technical solutions or complicated cleaning procedures implemented.

The results reported in literature indicate that the treatment of leachate requires biological procedures with activated sludge [38,39] and even phytoremediation methods [31]. Biological methods are characterized by varying effectiveness, which is related to higher biodegradability of leachate from young landfills compared to the old ones (reduction in the $\mathrm{BOD}_{5} / \mathrm{COD}$ ratio where $\mathrm{BOD}_{5}$ is five-day Biochemical Oxygen Demand) [40]. Therefore, landfill leachate introduced into biological wastewater treatment plants may have a negative influence on the microorganisms of the activated sludge and reduce the treatment efficiency. In particular, some chemical compounds present in landfill leachate, such as chlorobenzene, dichlorobenzene, chlorophenols, chloroaniline, toluene, ethylbenzene, xylene, phthalates and polycyclic aromatic hydrocarbons (PAHs) $[40,41]$ have a negative influence on the activity of activated sludge. For this reason, direct application of biological methods for leachate treatment before prior implementation of physicochemical methods is not always possible. Biological methods seem to be the most environmentally friendly, unfortunately, may show variable effectiveness due to changing concentrations of pollutants in the treated leachates.

Currently, more and more attention is being paid to such methods of leachate treatment which are environmentally friendly and do not cause additional negative effects. This concept is ideally suited to the method using potassium ferrate $(\mathrm{VI})\left(\mathrm{K}_{2} \mathrm{FeO}_{4}\right)$, which is an eco-friendly powerful oxidant with a dual mechanism of action. On the one hand, it acts in the oxidation of organic and partially inorganic pollutants (simultaneous reduction of $\mathrm{Fe}^{6+}$ to $\mathrm{Fe}^{3+}$ ), and in the coagulation of pollutants or oxidation products and their adsorption on the flocs of hydrated $\mathrm{Fe}(\mathrm{OH})_{3}$. Due to the fact that the decomposition products of $\mathrm{K}_{2} \mathrm{FeO}_{4}$ are iron oxides and oxygen, it is defined as a green oxidant and 
can be a promising alternative to the conventional coagulants [42]. Among others, potassium ferrate (VI) has been engaged for degradation of endocrine-disrupting compounds (EDCs), decomposition of surfactants (SPCs), personal care products (PCPs), pharmaceuticals [43], and also for oxidation of cyanides $\left(\mathrm{CN}^{-}\right)$originating from the mining and processing of gold ore, degradation of natural organic matter (NOM), oxidation of N,N-diethyl-3-toluamide (DEET), many dyes (Methylene Blue, Orange II, Brilliant Red X-3B, Acid Green 16), removal of algae [44] and for wastewater treatment [45].

The principal objective of the presented study was to assess the possibility of using $\mathrm{K}_{2} \mathrm{FeO}_{4}$ for the treatment of leachate from a municipal waste landfill and to select the most favorable conditions ( $\mathrm{pH}, \mathrm{K}_{2} \mathrm{FeO}_{4}$ conc., reaction time) for the treatment of leachate ensuring the maximum reduction of the $\mathrm{COD}$ value. Comparative studies were also carried out with the use of conventional coagulants $\left(\mathrm{FeSO}_{4}\right.$ $\times 7 \mathrm{H}_{2} \mathrm{O}, \mathrm{FeCl}_{3} \times 6 \mathrm{H}_{2} \mathrm{O}$ ) containing an equivalent amount of iron (in relation to the amount contained in the most favorable dose of $\mathrm{K}_{2} \mathrm{FeO}_{4}$ ) and the effect of the iron salts used on the concentration of Total Coli Count (TCC), Most Probable Number of fecal enterococci (MPN) and Total Proteolytic Count (TPC) in the treated leachate.

\section{Materials and Methods}

\subsection{Chemicals}

Envifer ${ }^{\circledR}$ (Nano Iron, Zidlochovice, Czech Republic) was engaged as the $\mathrm{K}_{2} \mathrm{FeO}_{4}$ source. Due to its chemical instability the content of $\mathrm{K}_{2} \mathrm{FeO}_{4}$ in Envifer ${ }^{\circledR}$ was specified directly before the procedures provided in the Analytical Procedures section. Envifer ${ }^{\circledR}$ was entirely characterized (UV-VIS spectrum, energy-dispersive $\mathrm{X}$-ray spectroscopy (EDXS) analysis, scanning electron microscopy (SEM) analysis) previously [46]. To adjust the leachate sample $\mathrm{pH}, 5 \%$ and $20 \%$ solutions of $\mathrm{H}_{2} \mathrm{SO}_{4}$ (Avantor ${ }^{\mathrm{TM}}$, Gliwice, Poland) was used. Solid $\mathrm{FeSO}_{4} \times 7 \mathrm{H}_{2} \mathrm{O}$ and $\mathrm{FeCl}_{3} \times 6 \mathrm{H}_{2} \mathrm{O}$ (Chempur, Piekary Ślaskie, Poland) were applied as conventional coagulants. For sludge flocculation a $0.05 \%$ solution of anionic flocculant Furoflock CW277 (Chemische Fabrik Wocklum Gebr. Hertin GmbH\&Co. KG, Balve, Germany) was employed. All chemicals (except $\mathrm{K}_{2} \mathrm{FeO}_{4}$ ) were of analytical grade. Additionally, deionized water $(<2 \mu \mathrm{S} / \mathrm{cm})$ was used for preparation and dilution of the solutions.

\subsection{Origin and Physicochemical Parameters of the Landfill Leachate}

Leachate from the old ( $>10$ years) municipal waste landfill located in southern Poland was investigated. The effluents were collected in summer during the rainy season (air temperature $25 \pm 1{ }^{\circ} \mathrm{C}$, precipitation $8 \mathrm{~mm}$ of water column) from the effluent reservoir, where it flowed through a system of drainage pipes. Fresh leachate (inflow) was collected within $24 \mathrm{~h}$, every hour, into sterile $1 \mathrm{~L}$ bottles, which were stored at the temperature of $4 \pm 1{ }^{\circ} \mathrm{C}$ without fixing the leachate before further investigation. The average sample of the leachate used for the test was obtained by mixing $1 \mathrm{~L}$ of unit samples in a sterile $25 \mathrm{~L}$ canister. The raw landfill leachate was analyzed as described in the Analytical Procedures section.

\subsection{Apparatus and Experiment Conditions}

All experiments were conducted at a constant temperature $\left(19 \pm 1^{\circ} \mathrm{C}\right)$, in beakers containing 250 $\pm 1 \mathrm{~mL}$ of tested leachates. The samples were mixed using a magnetic stirrer (MS11, Wigo, Pruszków, Poland) at a constant speed of $250 \mathrm{rpm}$ at the oxidation/coagulation stage and $50 \mathrm{rpm}$ at the flocculation stage. The experiments with $\mathrm{K}_{2} \mathrm{FeO}_{4}$ were carried out in such a way that $\mathrm{K}_{2} \mathrm{FeO}_{4}$ was added to the measured volume of wastewater, the $\mathrm{pH}$ was corrected with $20 \% \mathrm{H}_{2} \mathrm{SO}_{4}$ and the reaction was carried out for the assumed time span. The quantity of $\mathrm{K}_{2} \mathrm{FeO}_{4}, \mathrm{pH}$ and reaction time were set as predetermined at the stage of planning the experiments. After the oxidation/coagulation process was completed, the $\mathrm{pH}$ was adjusted to $9.0 \pm 0.1$ in each experiment using $20 \% \mathrm{NaOH}$ in order to precipitate the $\mathrm{Fe}^{3+}$ ions as $\mathrm{Fe}(\mathrm{OH})_{3}$. Subsequently, $0.25 \mathrm{~mL}$ of $0.05 \%$ Furoflock CW277 solution (anionic flocculant) was added, and the stirring speed was decreased to $50 \mathrm{rpm}$. After $30 \mathrm{sec}$, stirring was halted in order 
to sediment the formed precipitate. A sample of the liquid above the precipitate was collected and filtered using a $0.45 \mu \mathrm{m}$ PTFE syringe filter before COD determination. The filtrate was analysed according to the procedure provided in the Analytical Procedures section. Under the most favorable conditions of reducing the $\mathrm{COD}$ value $\left(\mathrm{pH}, \mathrm{K}_{2} \mathrm{FeO}_{4}\right.$ conc., reaction time), a verification experiment was carried out using sterile glass and laboratory equipment. In this case, a sample of treated leachate above the sediment was collected without filtering it through a $0.45 \mu \mathrm{m}$ PTFE syringe filter and microbiological tests were performed. Under the same conditions $(\mathrm{pH}$, reaction time), comparative tests were performed using an equivalent iron dose $\left(\mathrm{K}_{2} \mathrm{FeO}_{4}\right.$ vs. $\mathrm{FeSO}_{4} \times 7 \mathrm{H}_{2} \mathrm{O}$ and $\left.\mathrm{FeCl}_{3} \times 6 \mathrm{H}_{2} \mathrm{O}\right)$. In each case the treated leachate was analyzed as described in the Analytical Procedures section.

\subsection{Analytical Procedures}

Before performing the tests the chromite titration method was engaged to specify the content of $\mathrm{K}_{2} \mathrm{FeO}_{4}$ in Envifer ${ }^{\circledR}$. The above method is composed of oxidizing $\mathrm{Cr}(\mathrm{OH})_{4}{ }^{-}$ions using $\mathrm{FeO}_{4}{ }^{2-}$ under extremely alkaline conditions, which results in the generation of $\mathrm{Fe}(\mathrm{OH})_{3}, \mathrm{CrO}_{4}{ }^{2-}, \mathrm{OH}^{-}$. The $\mathrm{K}_{2} \mathrm{FeO}_{4}$ content in technical grade product (\%) was calculated using the following formula:

$$
\% \text { of } \mathrm{K}_{2} \mathrm{FeO}_{4}=\frac{c_{\mathrm{Fe}(\mathrm{II})} \times V_{\mathrm{Fe}(\mathrm{II})} \times \mathrm{M}_{\mathrm{K}_{2} \mathrm{FeO}} \times 100 \%}{3000 \times m_{\text {sample }}}
$$

where $c_{F e(I I)}$ and $V_{F e(I I)}$ are the concentration $(0.0850 \mathrm{~mol} / \mathrm{L})$ and the volume $(\mathrm{mL})$ of the standard Mohr's salt (ammonium iron(II) sulphate, $\left.\left(\mathrm{NH}_{4}\right)_{2} \mathrm{Fe}\left(\mathrm{SO}_{4}\right)_{2}\right)$ solution, $\mathrm{M}_{\mathrm{K}_{2} \mathrm{FeO}_{4}}$ is $198.04 \mathrm{~g} / \mathrm{mol}$, and $m_{\text {sample }}$ represents the sample weight $(\mathrm{g})$ [47]. The determination of the $\mathrm{K}_{2} \mathrm{FeO}_{4}$ content in Envifer ${ }^{\circledR}$ was also carried out spectrophotometrically (Cary ${ }^{\circledR} 50$ UV-VIS, Varian Inc., Melbourne, Australia) [48]. In this case, an Envifer ${ }^{\circledR}$ sample (with accuracy $\pm 0.001 \mathrm{~g}$ ) was dissolved in deionized water, and the volume was adjusted to $100 \mathrm{~mL}$ in a volumetric flask. Subsequently, the sample was filtered $(0.45 \mu \mathrm{m})$ into a quartz cuvette (light path $=10 \mathrm{~mm}$ ) and the absorbance values at $\lambda=505 \mathrm{~nm}$ was measured instantaneously. The $\mathrm{K}_{2} \mathrm{FeO}_{4}$ content in Envifer ${ }^{\circledR}(\%)$ was specified according to the following formula:

$$
\% \text { of } \mathrm{K}_{2} \mathrm{FeO}_{4}=\frac{A \times 0.1 \times \mathrm{M}_{\mathrm{K}_{2} \mathrm{FeO}_{4}} \times 100 \%}{1070 \times m_{\text {sample }}}
$$

where $A$ is the absorbance at $505 \mathrm{~nm}, M_{K_{2}} \mathrm{FeO}_{4}$ is $198.04 \mathrm{~g} / \mathrm{mol}, 1070$ is the molar absorbance coefficient, $\mathrm{M}^{-1} \mathrm{~cm}^{-1}$, and $m_{\text {sample }}$ represents the sample weight $(\mathrm{g})$.

The $\mathrm{pH}$-values and temperature were measured using an Inolab ${ }^{\circledR} \mathrm{pH} / \mathrm{Ion} / \mathrm{Cond} / \mathrm{Temp} 750 \mathrm{~m}$ and SenTix ${ }^{\circledR} 81$ electrodes (WTW, Weilheim in Oberbayern, Germany) [49]. The landfill leachate COD values were evaluated employing a dichromate method and the PF-11 spectrophotometer [50]. TOC was assayed using the tube test kit Nanocolor ${ }^{\circledR}$ TOC 60 , while the end-point was specified using the PF-11 spectrophotometer. TOC assessment was conducted in two stages. In the first one, inorganic carbon was eradicated from the samples by adding $\mathrm{NaHSO}_{4}$ and stirring the sample (500 rpm, $10 \mathrm{~min}$ ). In the second stage, organic compounds were degraded by application of $\mathrm{Na}_{2} \mathrm{~S}_{2} \mathrm{O}_{8}$ at $120{ }^{\circ} \mathrm{C}$ for $120 \mathrm{~min}$, and thymol blue absorbance variations of sodium salt solution were measured spectrophotometrically at $\lambda=585 \mathrm{~nm}$ [51]. Determination of Total Nitrogen (TN) was performed by two-step spectrophotometric method using Nanocolor ${ }^{\circledR}$ Total Nitrogen 220 test tube kit (Macherey-Nagel, Düren, Germany). In the first stage, the wastewater sample was mineralized $\left(\mathrm{Na}_{2} \mathrm{~S}_{2} \mathrm{O}_{8}, \mathrm{H}_{2} \mathrm{SO}_{4}, 120^{\circ} \mathrm{C}, 30 \mathrm{~min}\right)$, and in the second stage, spectrophotometric determination of nitrogen compounds after their reaction with 2,6-dimethylphenol (DMP, also commonly known as 2,6-xylenol), in a mixture of $\mathrm{H}_{2} \mathrm{SO}_{4}$ and $\mathrm{H}_{3} \mathrm{PO}_{4}$ were carried out [52]. Determination of Total Phosphorus (TP) was performed after effluent sample mineralization $\left(\mathrm{Na}_{2} \mathrm{~S}_{2} \mathrm{O}_{8}, \mathrm{H}_{2} \mathrm{SO}_{4}, 120{ }^{\circ} \mathrm{C}, 30 \mathrm{~min}\right)$ by using a test tube kit Nanocolor ${ }^{\circledR}$ ortho- and total Phosphate 15, with spectrophotometric endpoint detection using a PF-11 apparatus (Macherey-Nagel, Düren, Germany) [53]. The dilution of leachate samples before microbiological enumeration was performed according to ISO 6887-1:2017 [54]. The 
enumeration of Total Coli Count (TCC, CFU/mL), Total Proteolytic Count (TPC, CFU/mL) and the Most Probable Number of faecal enterococci (MPN/100 mL) were determined according to ISO 4832:2006 [55], PN-75/C-04615/17:1975 [56] and PN-C-04615-25:2008 [57], respectively. For the precipitation of gelatin in the Frazier's medium, Frazier's reagent (the mixture of $\mathrm{HgCl}_{2}, \mathrm{HCl}$ and $\mathrm{H}_{2} \mathrm{O}$ ) was used.

\subsection{Response Surface Methodology}

Central Composite Design (CCD) and Response Surface Methodology (RSM) were engaged to specify the most favorable conditions for lowering the COD landfill leachate value. The optimization of the COD removal process consisted of determining the numerical values of three independent variables $\left(\mathrm{pH}, \mathrm{K}_{2} \mathrm{FeO}_{4}\right.$ dose and reaction time) for which the value of the dependent parameter (COD) was the lowest. Based on the literature data on the implementation of $\mathrm{K}_{2} \mathrm{FeO}_{4}$ for the treatment of wastewater from various sources and taking into account the value of the redox potential for the $\mathrm{FeO}_{4}{ }^{2-}$ ion $\left(\mathrm{E}^{\circ}=+2.20 \mathrm{~V}\right.$ in acidic and $\mathrm{E}^{\circ}=+0.72 \mathrm{~V}$ in neutral media) and own experience, several preliminary experiments were carried out. The results of these experiments made it possible to approximate the $\mathrm{pH}, \mathrm{K}_{2} \mathrm{FeO}_{4}$ and reaction time adopted at the stage of planning experiments with the use of CCD. Therefore, the following values of input parameters were investigated: $\mathrm{pH}$ in the range $2-6, \mathrm{~K}_{2} \mathrm{FeO}_{4}$ dose $0.2-0.4 \mathrm{~g} / \mathrm{L}$ and reaction time 10-20 $\mathrm{min}$. The values of the remaining variables, including i.e., temperature, stirring speed, and volume of the treated wastewater sample were set as constant in each experiment, respectively. Table 1 reports the set-up of the 16 experiments designated by using CCD.

Table 1. Empirical conditions for the CCD/RSM and outcome (COD) for landfill leachate (pH 0.98-6.02, $\mathrm{K}_{2} \mathrm{FeO}_{4} 0.132-0.468 \mathrm{~g} / \mathrm{L}$, Time 6.59-23.41 min); (C)-center of the plan.

\begin{tabular}{|c|c|c|c|c|}
\hline \multirow{2}{*}{ Run } & \multicolumn{3}{|c|}{ Experimental Conditions } & \multirow{2}{*}{$\begin{array}{c}\text { Experimental Results * } \\
\mathrm{COD}\left(\mathrm{g} \mathrm{O}_{2} / \mathrm{L}\right)\end{array}$} \\
\hline & $\mathrm{pH}$ & $\mathrm{K}_{2} \mathrm{FeO}_{4}(\mathrm{~g} / \mathrm{L})$ & Time (min) & \\
\hline 1 & 2.00 & 0.200 & 10.00 & $0.385 \pm 0.058$ \\
\hline 2 & 2.00 & 0.200 & 20.00 & $0.355 \pm 0.053$ \\
\hline 3 & 2.00 & 0.400 & 10.00 & $0.295 \pm 0.044$ \\
\hline 4 & 2.00 & 0.400 & 20.00 & $0.260 \pm 0.039$ \\
\hline 5 & 5.00 & 0.200 & 10.00 & $0.465 \pm 0.070$ \\
\hline 6 & 5.00 & 0.200 & 20.00 & $0.450 \pm 0.068$ \\
\hline 7 & 5.00 & 0.400 & 10.00 & $0.300 \pm 0.045$ \\
\hline 8 & 5.00 & 0.400 & 20.00 & $0.295 \pm 0.044$ \\
\hline 9 & 0.98 & 0.300 & 15.00 & $0.245 \pm 0.037$ \\
\hline 10 & 6.02 & 0.300 & 15.00 & $0.495 \pm 0.074$ \\
\hline 11 & 3.50 & 0.132 & 15.00 & $0.695 \pm 0.104$ \\
\hline 12 & 3.50 & 0.468 & 15.00 & $0.205 \pm 0.031$ \\
\hline 13 & 3.50 & 0.300 & 6.59 & $0.345 \pm 0.052$ \\
\hline 14 & 3.50 & 0.300 & 23.41 & $0.240 \pm 0.036$ \\
\hline $15(\mathrm{C})$ & 3.50 & 0.300 & 15.00 & $0.265 \pm 0.040$ \\
\hline $16(\mathrm{C})$ & 3.50 & 0.300 & 15.00 & $0.275 \pm 0.041$ \\
\hline
\end{tabular}

The obtained empirical findings (the arithmetic mean of three runs was adopted) were investigated statistically; and the impact of the independent (input) variables ( $\mathrm{pH}$, concentration of $\mathrm{K}_{2} \mathrm{FeO}_{4}(\mathrm{~g} / \mathrm{L})$, and reaction time (min)) on the dependent (output) parameter (COD, $\mathrm{g} \mathrm{O}_{2} / \mathrm{L}$ ) was illustrated as a response surface graph. For the most favorable values of the three input parameters, an experimental verification of the model was carried out (additionally, the COD changes after $25 \mathrm{~min}, 30 \mathrm{~min}, 35 \mathrm{~min}$ and 40 min reaction time were investigated). 


\section{Results and Discussion}

\subsection{Physicochemical Parameters of the Landfill Leachate and $\mathrm{K}_{2} \mathrm{FeO}_{4}$}

The physicochemical analysis of technical grade potassium ferrate (VI) showed that it contained $40 \%$ of pure $\mathrm{K}_{2} \mathrm{FeO}_{4}$. Additionally, previous research revealed that it was composed of $47.31 \% \pm$ $1.50 \% \mathrm{~K}, 15.00 \% \pm 0.45 \% \mathrm{Fe}$, and $37.69 \% \pm 5.20 \% \mathrm{O}$, along with impurities such as $\mathrm{K}_{2} \mathrm{O}$ and ferrous compounds other than $\mathrm{K}_{2} \mathrm{FeO}_{4}$ (i.e., $\mathrm{K}_{3} \mathrm{FeO}_{4}$ and $\mathrm{KFeO}_{2}$ ). It was probably related to the method used at the stage of its synthesis [46].

Table 2 presents chosen physicochemical and microbiological variables of the landfill leachate.

Table 2. The specified physicochemical and microbiological parameters of the landfill leachate.

\begin{tabular}{ccc}
\hline Parameter & Unit & Result $^{*}$ \\
\hline $\mathrm{pH}$ & - & $8.9 \pm 0.1$ \\
Chemical Oxygen Demand, COD & $\mathrm{mg} \mathrm{O}_{2} / \mathrm{L}$ & $770 \pm 116$ \\
Total Organic Carbon, TOC & $\mathrm{mg} / \mathrm{L}$ & $230 \pm 35$ \\
Total Nitrogen, TN & $\mathrm{mg} / \mathrm{L}$ & $120 \pm 18$ \\
Total Phosphorus, TP & $\mathrm{mg} / \mathrm{L}$ & $12 \pm 2$ \\
Total Coli Count, TCC & $\mathrm{CFU} / \mathrm{mg} / \mathrm{L}$ & $6.2 \times 10^{6}(6.8 \mathrm{log})$ \\
Most Probable Number of fecal enterococci, $\mathrm{MPN}_{\mathrm{fe}}$ & $\mathrm{MPN} / 100 \mathrm{~mL}$ & $1.1 \times 10^{4}(4.0 \mathrm{log})$ \\
Total Proteolytic Count, TPC & $\mathrm{CFU} / \mathrm{mL}$ & $2.6 \times 10^{4}(4.4 \mathrm{log})$ \\
\hline${ }^{*}$ parameter value \pm the measurement uncertainty for an extension factor $k=2$; for $\mathrm{pH} \pm 0.1$, for COD, TOC, TN and \\
TP the measurement uncertainty was $\pm 15 \%$, for microbiological enumerations the measurement uncertainty were \\
0.04 log (TCC, TPC) and $0.07 \log \left(\mathrm{MPN}_{\mathrm{fe}}\right)$.
\end{tabular}

Initiatory specification of the chosen physicochemical and microbiological parameters of the landfill leachate unveiled that they were slightly alkaline $(\mathrm{pH}=8.9)$ and contained a certain amount of organic compounds expressed as chemical oxygen demand and total organic carbon (COD $770 \mathrm{mg} \mathrm{O} / \mathrm{L}$ and TOC $230 \mathrm{mg} / \mathrm{L}$, respectively). Additionally, the content of organic (and probably inorganic) nitrogen compounds in the tested leachates was specified by the content of total nitrogen and phosphorus (TN $120 \mathrm{mg} / \mathrm{L}$ and TP $12 \mathrm{mg} / \mathrm{L}$, respectively).

On the other hand, the conducted microbiological tests showed significant contamination of the investigated leachates with coliforms, fecal bacteria and proteolytic bacteria (TCC $6.8 \log$ CFU/mL, MPN $4.0 \mathrm{log} / 100 \mathrm{~mL}$ and $4.4 \log \mathrm{CFU} / \mathrm{mL}$, respectively). The obtained test results are comparable with the previous findings, especially for leachate from old landfills, for which a decrease in the value of pollution indicators was observed. Generally, in the case of pH-value values were 4-9.5 [4-12], for COD 100-84 $300 \mathrm{mg} \mathrm{O}_{2} / \mathrm{L}[4,13-16]$ and for TOC 40-13 $610 \mathrm{mg} / \mathrm{L}$. In addition, for TN and TP, the values were $350-4.370 \mathrm{mg} / \mathrm{L}$ and 1-655 mg/L, respectively [18,24-31]. The parameter values presented in Table 2 indicate that the tested leachate did come from the old landfill and was collected during the rainy season, as presented in the section concerning origin and physicochemical parameters of the landfill leachate. Other studies indicated the presence of pathogenic bacteria, not only in the leachate, but also in groundwater as a result of leachate infiltration into the ground (coliform bacteria, Escherichia coli, Enterococci, Pseudomonas aeruginosa). In groundwater, high concentrations of coliform bacteria (20,000 CFU/100 mL), Escherichia coli $(15,199 \mathrm{CFU} / 100 \mathrm{~mL})$ and Enterococci $(3290 \mathrm{CFU} / 100 \mathrm{~mL})$ were specified [58]. The conducted studies of leachate revealed that in the event of their uncontrolled release, they may have a negative impact on the natural environment.

\subsection{CCD/RSM Findings}

The employment of CCD and RSM in investigation planning enabled 16 experiments to be performed (see Table 2). The findings of COD values $\left(\mathrm{g} \mathrm{O}_{2} / \mathrm{L}\right)$ linked to each experiment are reported in Table 2 (see column 5). The lowest COD values $\left(<0.25 \mathrm{~g} \mathrm{O}_{2} / \mathrm{L}\right)$ were recorded in experiments 9,12 , and $14\left(0.245,0.205,0.240 \mathrm{~g} \mathrm{O}_{2} / \mathrm{L}\right)$, respectively. In the experiment number 12 , the highest dose of 
$\mathrm{K}_{2} \mathrm{FeO}_{4}(0.468 \mathrm{~g} / \mathrm{L})$ was used at $\mathrm{pH} 3.5$ during $15 \mathrm{~min}$, and the lowest COD value was obtained for the purified effluents $\left(0.205 \mathrm{~g} \mathrm{O}_{2} / \mathrm{L}\right)$. This indicates a significant influence of the $\mathrm{K}_{2} \mathrm{FeO}_{4}$ dose on the COD value of the effluents, along with other parameters ( $\mathrm{pH}$-value and reaction time).

Table 3 presents the evaluation of the parameters and their influence of the COD of the landfill leachate.

Table 3. Statistical parameters of the experiments using CCD/RSM with Statistica 13-evaluation of the effects.

\begin{tabular}{|c|c|c|c|c|c|c|c|c|c|}
\hline \multirow{2}{*}{ Parameter } & \multicolumn{9}{|c|}{ Evaluation of the Effects, COD, $\mathrm{g} \mathrm{O}_{2} / \mathrm{L}, R^{2}=0.8477, R_{a d j}^{2}=0.7462,3$ Parameter, 1 Block, 16 Experiments, $\mathrm{MS}=0.0040$} \\
\hline & Effect & $\begin{array}{l}\text { Standard } \\
\text { Error }\end{array}$ & $p$-Value ${ }^{*}$ & $\begin{array}{c}-95 \% \\
\text { Confidence } \\
\text { Interval }\end{array}$ & $\begin{array}{c}+95 \% \\
\text { Confidence } \\
\text { Interval }\end{array}$ & Factor & $\begin{array}{l}\text { Standard } \\
\text { Error of } \\
\text { Factor }\end{array}$ & $\begin{array}{c}\text { Lower } \\
\text { Confidence } \\
\text { Interval }\end{array}$ & $\begin{array}{c}\text { Upper } \\
\text { Confidence } \\
\text { Interval }\end{array}$ \\
\hline Constant Value & 0.2725 & 0.0448 & 0.0002 & 0.1713 & 0.3738 & 0.2725 & 0.0448 & 0.1713 & 0.3738 \\
\hline $\mathrm{pH}(\mathrm{L})$ & 0.0931 & 0.0344 & 0.0240 & 0.0153 & 0.1708 & 0.0465 & 0.0172 & 0.0077 & 0.1708 \\
\hline $\mathrm{pH}(\mathrm{Q})$ & 0.0584 & 0.0417 & 0.1947 & -0.0359 & 0.1528 & 0.0292 & 0.0209 & -0.0180 & 0.1528 \\
\hline Time (L) & 0.0383 & 0.0344 & 0.2937 & -0.1160 & 0.0394 & -0.0192 & 0.0172 & -0.0580 & 0.0394 \\
\hline Time (Q) & 0.0036 & 0.0417 & 0.9323 & -0.0907 & 0.0980 & 0.0018 & 0.0209 & -0.0454 & 0.0980 \\
\hline
\end{tabular}

L-linear effect, Q-quadratic effect, ${ }^{*}$ statistically significant if $p<0.05$.

The constant value, $\mathrm{pH}(\mathrm{L}), \mathrm{K}_{2} \mathrm{FeO}_{4}(\mathrm{~L})$ and $\mathrm{K}_{2} \mathrm{FeO}_{4}(\mathrm{Q})$, concentration were specified to be statistically valid $(p<0.05)$, while the $\mathrm{pH}(\mathrm{Q})$, Time $(\mathrm{L})$ and Time $(\mathrm{Q})$ were not statistically significant $(p>0.05)$. Moreover, the values of the calculated determination coefficient $\mathrm{R}^{2}$ and the adjusted determination coefficient $\mathrm{R}^{2}$ adj $(0.8477$ vs. 0.7462$)$ depicted the ratio of the variance in the dependent variable (COD) that was foreseen based on the independent variables ( $\mathrm{pH}$-value, $\mathrm{K}_{2} \mathrm{FeO}_{4}$ conc. and time).

In the case of the real sewage from the textile industry, $\mathrm{R}^{2}$ and $\mathrm{R}^{2}$ adj reached values of 0.8799 and 0.7999 [45]. In the case of using $\mathrm{K}_{2} \mathrm{FeO}_{4}$ for the treatment of wastewater from the tanning industry other studies have reported $R^{2}$ and $R^{2}$ adj values of 0.77 and 0.59 [59] versus 0.95 and 0.74 in the case of employing $\mathrm{K}_{2} \mathrm{FeO}_{4}$ for the treatment of synthetic sewage containing azo dye Anilan Blue GRL $250 \%$ [60]. A good fit between the empirical and approximated data was observed in the latter study.

Table 4 reports the outcome of verifying the adequacy of the model coefficients using ANOVA, which confirmed the statistical significance $(p<0.05)$ of the main input parameters i.e., $\mathrm{pH}(\mathrm{L}), \mathrm{K}_{2} \mathrm{FeO}_{4}$ (L) and $\mathrm{K}_{2} \mathrm{FeO}_{4}(\mathrm{Q})$. These findings are also presented graphically in a form of bar chart (see Figure 1).

Table 4. Analysis of the CCD/RSM experiment using Statistica 13-verification of the adequacy of the model using ANOVA.

\begin{tabular}{|c|c|c|c|c|}
\hline \multirow[t]{2}{*}{ Parameter } & \multicolumn{4}{|c|}{$\begin{array}{c}\text { Assessment of Effects, } \mathrm{COD}, \mathrm{g} \mathrm{O}_{2} / \mathrm{L}, R^{2}=0.8477, R^{2} \text { adj }=0.7462,3 \text { Parameter, } 1 \text { Block, } \\
16 \text { Experiments, } \mathrm{MS}=0.0040\end{array}$} \\
\hline & SS & MS & F & $p^{*}$ \\
\hline $\mathrm{pH}(\mathrm{L})$ & 0.029567 & 0.029567 & 7.33757 & 0.024045 \\
\hline $\mathrm{pH}(\mathrm{Q})$ & 0.007911 & 0.007911 & 1.96337 & 0.194681 \\
\hline $\mathrm{K}_{2} \mathrm{FeO}_{4}(\mathrm{~L})$ & 0.129345 & 0.129345 & 32.09914 & 0.000307 \\
\hline $\mathrm{K}_{2} \mathrm{FeO}_{4}(\mathrm{Q})$ & 0.030637 & 0.030637 & 7.60318 & 0.022207 \\
\hline Time (L) & 0.005011 & 0.005011 & 1.24345 & 0.293696 \\
\hline Time (Q) & 0.000031 & 0.000031 & 0.00764 & 0.932269 \\
\hline Error & 0.036266 & 0.004030 & - & - \\
\hline
\end{tabular}

L-linear effect, Q-quadratic effect, SS-predicted residual error of sum of squares, MS-mean square error, F-statistics, * statistically significant if $p<0.05$. 


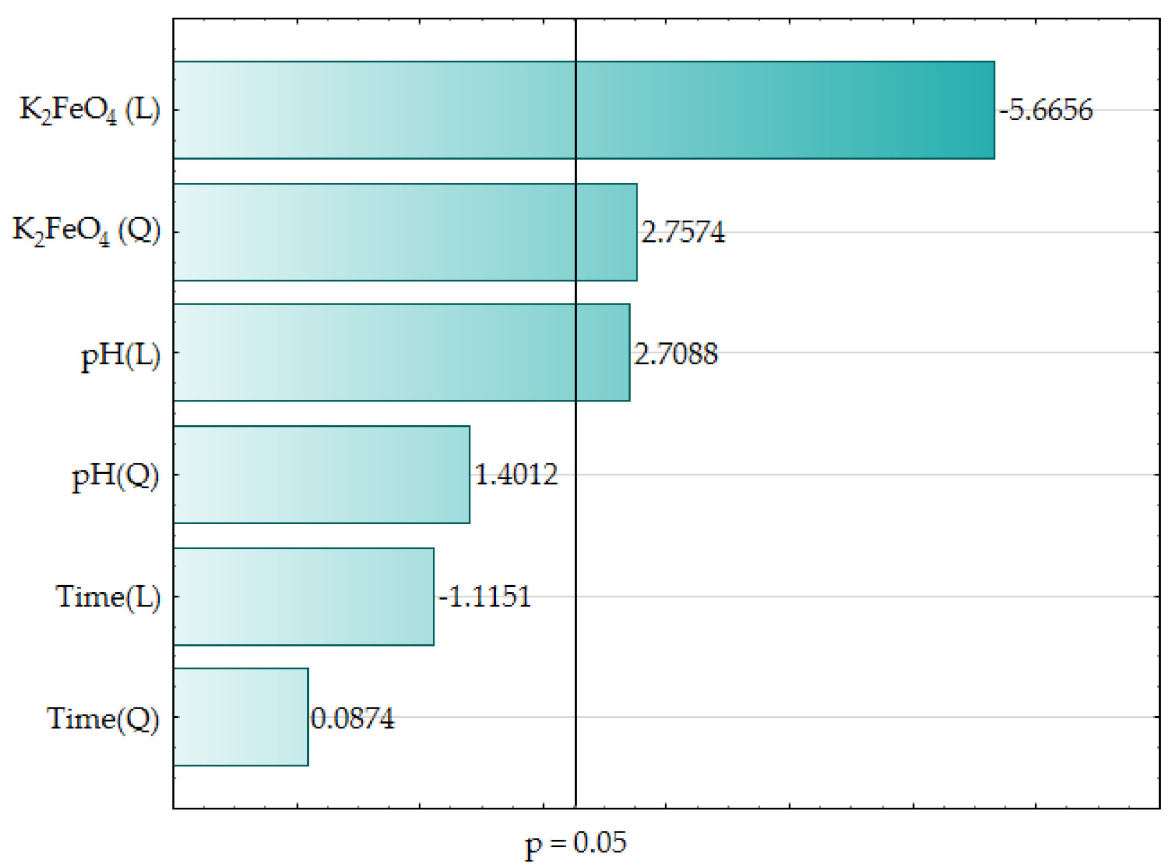

Figure 1. Bar chart of standardized effects (COD, $\mathrm{g} \mathrm{O}_{2} / \mathrm{L}, 3$ value, 1 block, 16 experiments, $\mathrm{MS}=0.0040$, L-linear effect, Q-quadratic effect, p-the absolute value of the standardized effect evaluation).

The estimators of the standardized effects were prioritized according to their absolute value; the vertical line pinpoints the minimum absolute value for statistical significance. In the investigated wastewater samples, $\mathrm{K}_{2} \mathrm{FeO}_{4}(\mathrm{~L}), \mathrm{K}_{2} \mathrm{FeO}_{4}(\mathrm{Q})$, and $\mathrm{pH}(\mathrm{L})$, revealed the largest impact on decreasing the COD value under the empirical conditions. The other parameters i.e., $\mathrm{pH}(\mathrm{Q})$, Time (L), time $(\mathrm{Q})$ exerted the smallest impact on the COD value. Figure 2 presents the relationship between the predicted COD value and observed COD value.

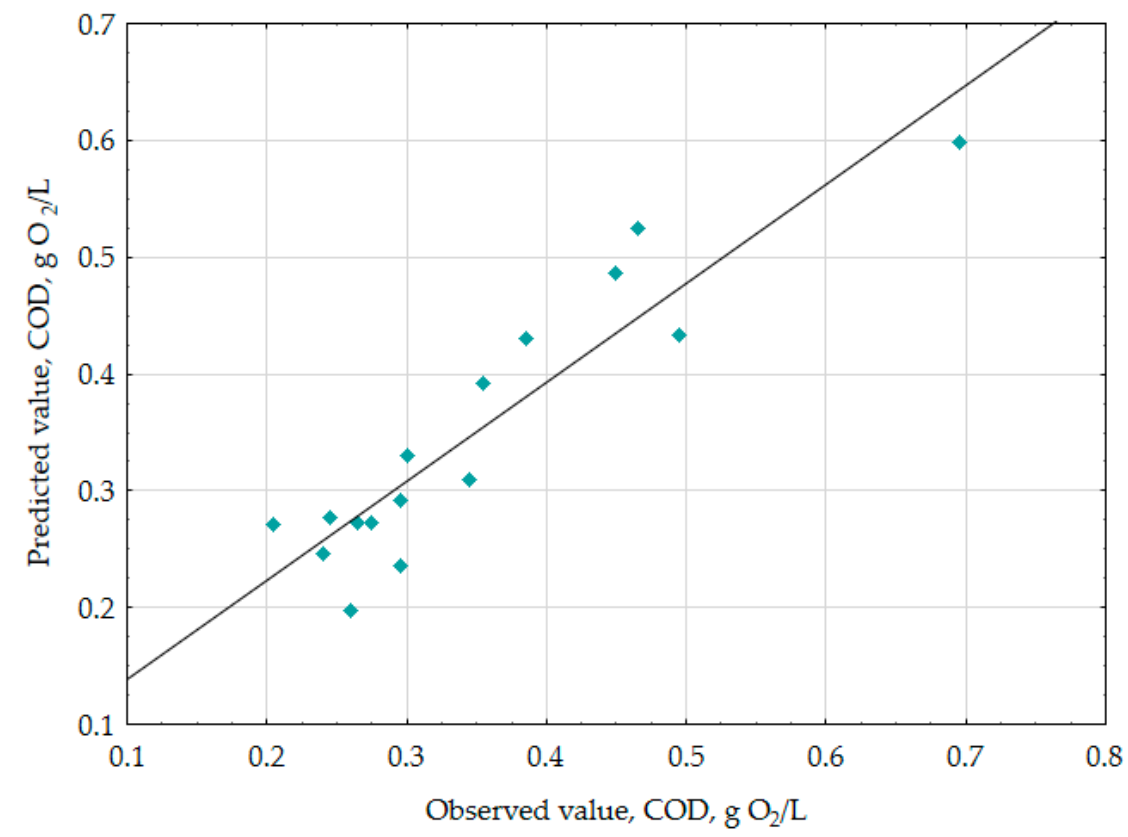

Figure 2. Predicted vs. observed values plots for $\operatorname{COD}\left(\mathrm{g} \mathrm{O}_{2} / \mathrm{L}\right)$.

The data presented a linear correlation between the empirical and approximated data in the range of verified COD values. Figure 3 illustrates the response surface plots for COD with respect to $\mathrm{K}_{2} \mathrm{FeO}_{4}$ conc. and $\mathrm{pH}$, Time and $\mathrm{pH}$ and Time and to $\mathrm{K}_{2} \mathrm{FeO}_{4}$ conc. (see Figure $3 \mathrm{~A}-\mathrm{C}$ ). 

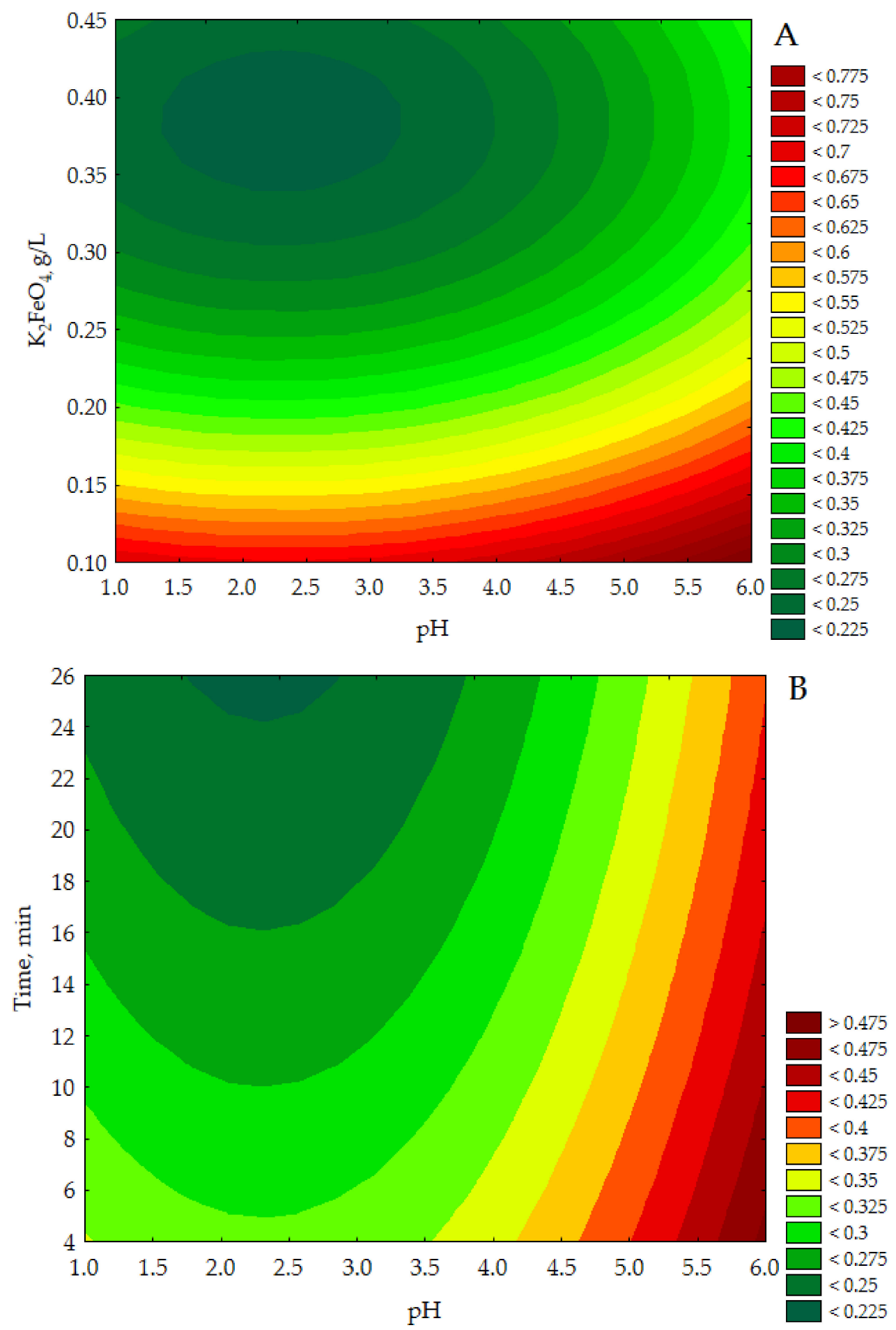

Figure 3. Cont. 


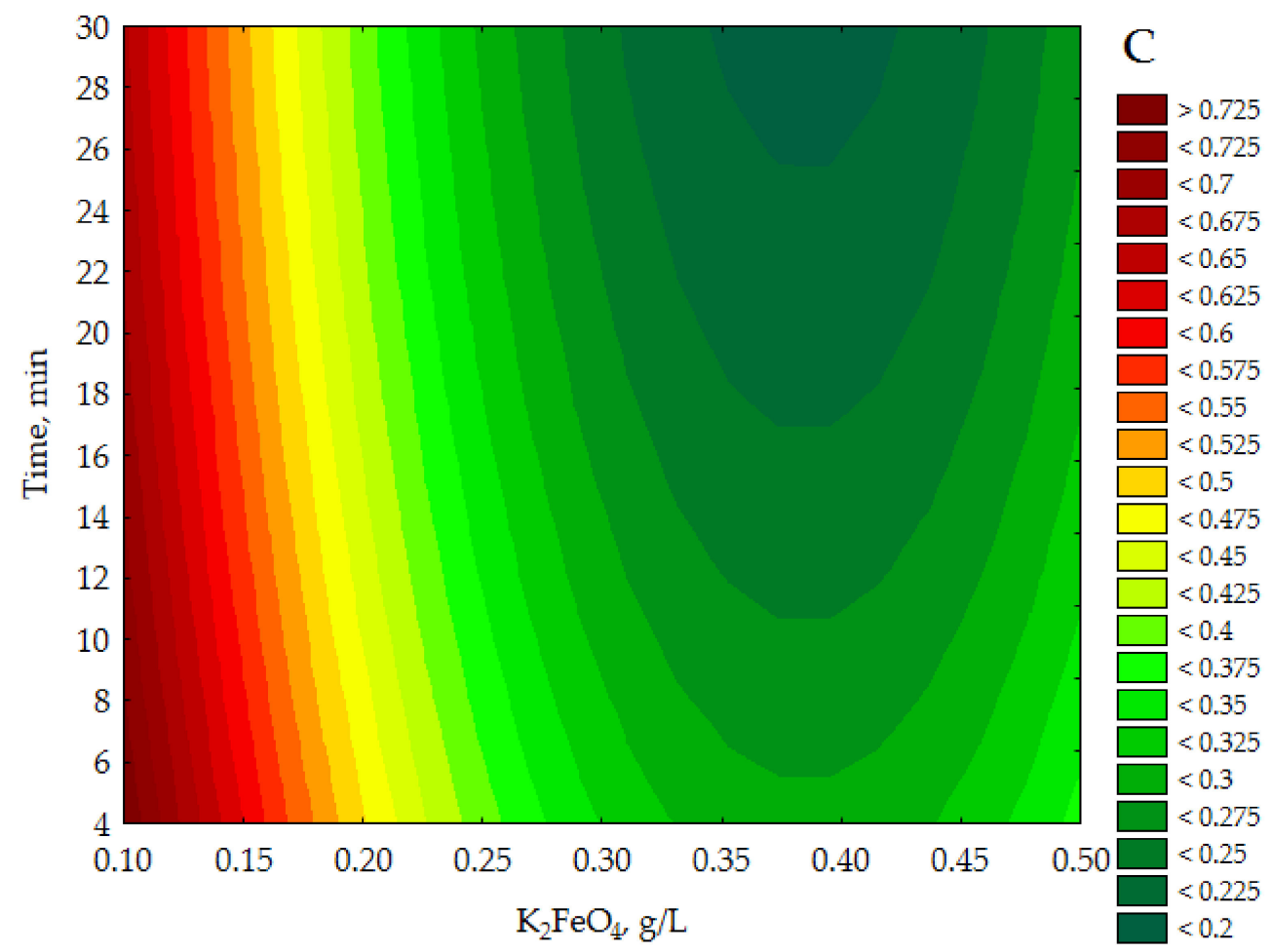

Figure 3. Response surface plots for $\mathrm{COD}\left(\mathrm{g} \mathrm{O}_{2} / \mathrm{L}\right)$ with respect to $\mathrm{K}_{2} \mathrm{FeO}_{4}(\mathrm{~g} / \mathrm{L})$ and $\mathrm{pH}(\mathrm{A})$, time (min), and $\mathrm{pH}(\mathrm{g} / \mathrm{L})(\mathbf{B})$ and time $(\mathrm{min})$ and $\mathrm{K}_{2} \mathrm{FeO}_{4}(\mathrm{~g} / \mathrm{L})(\mathbf{C})$.

The CCD/RSM study showed (see Figure 3A) that the lowest COD value $\left(<0.225 \mathrm{~g} \mathrm{O}_{2} / \mathrm{L}\right)$ was obtained for $\mathrm{K}_{2} \mathrm{FeO}_{4}$ approx. $0.34-0.43 \mathrm{~g} / \mathrm{L}$ and a pH between 1.4-3.3 with the time parameter set at $15 \mathrm{~min}$. It can be seen in Figure 3B that for a constant dose of $\mathrm{K}_{2} \mathrm{FeO}_{4} 0.300 \mathrm{~g} / \mathrm{L}$ the lowest COD values $\left(<0.225 \mathrm{~g} \mathrm{O}_{2} / \mathrm{L}\right)$ were specified for $\mathrm{pH}$ approx. 1.7-2.9 in more than $25 \mathrm{~min}$. In turn, the data presented in Figure $3 \mathrm{C}$ indicate that the adoption of a constant $\mathrm{pH}$ value of 3.5 allows to obtain the lowest COD values of purified effluents $(<0.200 \mathrm{~g} / \mathrm{L})$ for $\mathrm{K}_{2} \mathrm{FeO}_{4}$ conc. approx. $0.35-0.43 \mathrm{~g} / \mathrm{L}$ over a time greater than $25 \mathrm{~min}$. The presented results of model tests show that the lowest COD values for purified leachates were determined for the highest doses of $\mathrm{K}_{2} \mathrm{FeO}_{4}$ used in the experiments, in the acidic environment $(1.7<\mathrm{pH}<3.3)$ for more than $25 \mathrm{~min}$.

The generated test results correspond to the literature data, which indicate that the value of the redox potential for the $\mathrm{FeO}_{4}{ }^{2-}$ ion is greater in an acidic environment than in a neutral environment $\left(\mathrm{E}^{\circ}\right.$ $=+2.20 \mathrm{~V}$ in acidic and $\mathrm{E}^{\circ}=+0.72 \mathrm{~V}$ in neutral media). Generally, greater efficiency of the oxidation of organic compounds can be observed, while conducting the oxidation process in an acidic environment, rather than in a neutral one $[43,44]$. Another study indicated that use of $\mathrm{K}_{2} \mathrm{FeO}_{4}$ for the purification of highly polluted tannery wastewater from leather dyeing processes resulted in the discoloration (98.4\% removal), chemical oxygen demand (77.2\% removal), total organic carbon (75.7\% removal), and suspended solids (96.9\% removal); the reported values were the smallest when $1.200 \mathrm{~g} / \mathrm{L} \mathrm{K}_{2} \mathrm{FeO}_{4}$ at $\mathrm{pH} 3$ within 9 min was used [59]. On the other hand, the application of $\mathrm{K}_{2} \mathrm{FeO}_{4}$ for the degradation of trichloroacetic acid and turbidity removal in synthetic water revealed that the highest efficiency achieved for trichloroacetic acid was $24 \%$, while for turbidity the maximum removal efficiency was in the range of $85 \%-95 \%$. Additionally, the optimum conditions for initial turbidity, $\mathrm{pH}$, and ferrate (VI) dosage were $8.89 \mathrm{NTU}, 3$, and $4.26 \mathrm{mg} / \mathrm{L}$ as Fe, respectively [61]. Other study indicates that the leachate treatment is also possible in an alkaline condition. In this case the $\mathrm{pH}$ value was 10 , the dosage of $\mathrm{K}_{2} \mathrm{FeO}_{4}$ was $6 \mathrm{~g} / \mathrm{L}$ and the reaction time was $30 \mathrm{~min}$. Unfortunately, the experiment required an additional use of a stabilizer at a dose $4 \mathrm{~g} / \mathrm{L}$ (sodium silicate, $\mathrm{Na}_{2} \mathrm{SiO}_{3}$ ). Under those conditions, the COD removal efficiency was only $36 \%$ [62] compared to $76.2 \%$ in this study. An application of $\mathrm{K}_{2} \mathrm{FeO}_{4}$ in the leachate treatment at the higher temperature $\left(30^{\circ} \mathrm{C}\right)$ by the initial ferrate (VI) to COD 
mass concentration ratio of $0.50, \mathrm{pH} 4.00$ and reaction time $40 \mathrm{~min}$ was suggested as well. It was stated that the leachate from hazardous waste landfill which was pretreated by $\mathrm{K}_{2} \mathrm{FeO}_{4}$ could be directly discharged into the biological treatment system. However, COD value of leachates from the refuse incineration plant which was pretreated by $\mathrm{K}_{2} \mathrm{FeO}_{4}$ was as much as $2861 \mathrm{mg} \mathrm{O} / \mathrm{L}$. These leachates required re-treatment before the introduction into the subsequent biochemical treatment system [63].

Moreover, it should be taken into account that the total efficiency of removing organic (and partially inorganic) compounds expressed as COD, TOC, TN and TP results not only from their oxidation by $\mathrm{Fe}^{+6}$, but also to some extent from their adsorption on freshly precipitated $\mathrm{Fe}(\mathrm{OH})_{3}$ flocs with a large active surface. In the case of phosphorus compounds (present as $\mathrm{PO}_{4}{ }^{3-}$ ), it is possible to remove them by co-precipitation with $\mathrm{Fe}^{3+}$ ions, which results in the formation of hardly soluble ferric phosphate. To sum up, it should be stated that under the experimental conditions, the total efficiency of removing contaminants expressed as COD resulted from their oxidation and coagulation and, probably, to some extent from adsorption and co-precipitation. Table 5 presents the calculated coefficients of the fitted model.

Table 5. Coefficients of the fitted model.

\begin{tabular}{ccccccc}
\hline Predictor & $\begin{array}{c}\text { Regression } \\
\text { Coefficient }\end{array}$ & $\begin{array}{c}\text { Standard } \\
\text { Error }\end{array}$ & $\begin{array}{c}\mathbf{t} \text {-Value, } \\
\boldsymbol{d f = 9}\end{array}$ & $\boldsymbol{p}$-Value & $\begin{array}{c}\mathbf{- 9 5 \%} \\
\text { Confidence } \\
\text { Interval }\end{array}$ & $\begin{array}{c}\mathbf{+ 9 5 \%} \\
\text { Confidence } \\
\text { Interval }\end{array}$ \\
\hline Intercept & 1.206468 & 0.354637 & 3.401978 & 0.007849 & 0.404223 & 2.008712 \\
$\mathrm{pH}(\mathrm{L})$ & -0.059897 & 0.065887 & -0.909076 & 0.387006 & -0.208944 & 0.089151 \\
$\mathrm{pH}(\mathrm{Q})$ & 0.012988 & 0.009269 & 1.401202 & 0.194681 & -0.007980 & 0.033957 \\
$\mathrm{~K}_{2} \mathrm{FeO}_{4}(\mathrm{~L})$ & -4.423640 & 1.263080 & -3.502263 & 0.006700 & -7.280926 & -1.566353 \\
$\mathrm{~K}_{2} \mathrm{FeO}_{4}(\mathrm{Q})$ & 5.750741 & 2.085576 & 2.757387 & 0.022207 & 1.032839 & 10.468642 \\
$\mathrm{Time}_{(\mathrm{L})}$ & -0.006018 & 0.025262 & -0.238234 & 0.817035 & -0.063164 & 0.051128 \\
Time (Q) & 0.000073 & 0.000834 & 0.087398 & 0.932269 & -0.001814 & 0.001960 \\
\hline
\end{tabular}

$d f$-degree of freedom.

Consequently, the changes in the COD value can be calculated according to the following formula:

$$
\begin{gathered}
\operatorname{COD}\left(\mathrm{g} \mathrm{O}_{2} / \mathrm{L}\right)=1.206468-0.059897(\mathrm{pH})+0.012988(\mathrm{pH})^{2}-4.423640\left(\mathrm{~K}_{2} \mathrm{FeO}_{4}\right) \\
+5.750741\left(\mathrm{~K}_{2} \mathrm{FeO}_{4}\right)^{2}-0.006018(\text { Time })+0.000073(\text { Time })^{2}
\end{gathered}
$$

For the most favorable values of the three input parameters $\left(\mathrm{pH}=2.31, \mathrm{~K}_{2} \mathrm{FeO}_{4} 0.38 \mathrm{~g} / \mathrm{L}\right.$ and Time $41 \mathrm{~min}$ ) calculated from the model, the estimated COD value was $162 \mathrm{mg} \mathrm{O} / \mathrm{L}$. In the conducted verification experiment, the COD value was $178 \mathrm{mg} \mathrm{O}_{2} / \mathrm{L}$. Assuming that the uncertainty of COD determination is $\pm 15 \%$, the actual COD value of sewage treated under the most favorable conditions is in the range from 151 to $205 \mathrm{mg} \mathrm{O}_{2} / \mathrm{L}\left(180 \pm 27 \mathrm{mg} \mathrm{O}_{2} / \mathrm{L}\right)$, which also includes the estimated value from model for the most favorable $\mathrm{pH}$ values, $\mathrm{K}_{2} \mathrm{FeO}_{4}$ and time.

For a constant $\mathrm{pH}$ value 3.5 (see Figure $3 \mathrm{~B}$ ) the lowest COD values $(<200 \mathrm{mg} \mathrm{O} / \mathrm{L}$ ) were obtained after 25 min of reaction time, therefore an additional verification experiment was carried out for the $\mathrm{pH}$ value and $\mathrm{K}_{2} \mathrm{FeO}_{4}$ concentration estimated from the model for the most favorable conditions (i.e., $2.31 \mathrm{~g} / \mathrm{L}$ and $0.38 \mathrm{~g} / \mathrm{L}$, respectively), and the COD was determined after $25 \mathrm{~min}, 30 \mathrm{~min}, 35 \mathrm{~min}$ and $40 \mathrm{~min}$ reaction time. The subsequent COD values of the treated effluents were $180 \pm 27 \mathrm{mg} \mathrm{O} 2 / \mathrm{L}, 172$ $\pm 26 \mathrm{mg} \mathrm{O}_{2} / \mathrm{L}, 170 \pm 26 \mathrm{mg} \mathrm{O}_{2} / \mathrm{L}, 168 \pm 25 \mathrm{mg} \mathrm{O}_{2} / \mathrm{L}$, respectively. Considering the uncertainty of the COD determination $( \pm 15 \%)$, it was found that the COD of the treated leachate was not significantly reduced. Therefore, the most favorable values for the independent parameters i.e., $\mathrm{pH}=2.3 \pm 0.1$, $\mathrm{K}_{2} \mathrm{FeO}_{4} 0.390 \pm 0.001 \mathrm{~g} / \mathrm{L}$ and Time $25 \pm 1 \mathrm{~min}$ were adopted. Under these conditions, a reduction in TOC, TN and TP was also observed $(82.6 \%, 68.3 \%, 91.6 \%$, respectively) as shown in Table 6 (column 3 ). 
Table 6. Selected physicochemical parameters of treated landfill leachate after $\mathrm{K}_{2} \mathrm{FeO}_{4}, \mathrm{FeSO}_{4} \times 7 \mathrm{H}_{2} \mathrm{O}$ and $\mathrm{FeCl}_{3} \times 6 \mathrm{H}_{2} \mathrm{O}$ application.

\begin{tabular}{|c|c|c|c|c|}
\hline \multirow[t]{2}{*}{ Parameter * } & \multirow[t]{2}{*}{ Unit } & $\begin{array}{c}\text { After } \mathrm{K}_{2} \mathrm{FeO}_{4} \\
\text { Application in Optimal } \\
\text { Conditions }\end{array}$ & $\begin{array}{c}\text { After } \mathrm{FeSO}_{4} \times 7 \mathrm{H}_{2} \mathrm{O} \\
\text { Application } * * *\end{array}$ & $\begin{array}{c}\text { After } \mathrm{FeCl} \times 6 \mathrm{H}_{2} \mathrm{O} \\
\text { Application } \\
* * * *\end{array}$ \\
\hline & & \multicolumn{3}{|c|}{ Removal, \% (in Brackets) ***** } \\
\hline $\mathrm{pH}$ & - & $9.0 \pm 0.1$ & $9.0 \pm 0.1$ & $9.0 \pm 0.1$ \\
\hline Chemical Oxygen Demand & $\mathrm{mg} \mathrm{O}_{2} / \mathrm{L}$ & $180 \pm 27(\downarrow 76.2)$ & $475 \pm 71(\downarrow 38.1)$ & $450 \pm 68(\downarrow 41.6)$ \\
\hline Total Organic Carbon & $\mathrm{mg} / \mathrm{L}$ & $40 \pm 6(\downarrow 82.6)$ & $145 \pm 22(\downarrow 37.0)$ & $125 \pm 19(\downarrow 45.7)$ \\
\hline Total Nitrogen, TN & $\mathrm{mg} / \mathrm{L}$ & $38 \pm 6(\downarrow 68.3)$ & $95 \pm 14(\downarrow 20.8)$ & $85 \pm 13(\downarrow 29.2)$ \\
\hline Total Phosphorus, TP & $\mathrm{mg} / \mathrm{L}$ & $1.0 \pm 0.2(\downarrow 91.6)$ & $0.50 \pm 0.08(\downarrow 95.8)$ & $0.5 \pm 0.08(\downarrow 95.8)$ \\
\hline Total Coli Count, TCC & $\mathrm{CFU} / \mathrm{mL}$ & $5.9 \times 10^{2} ; 2.8 \log (\downarrow 99.9)$ & $3.5 \times 10^{5} ; 5.5 \log (\downarrow 94.4)$ & $\begin{array}{c}4.9 \times 10^{5} ; 5.7 \log \\
(\downarrow 92.1)\end{array}$ \\
\hline $\begin{array}{l}\text { Most Probable Number } \\
\text { of fecal enterococci, MPN }\end{array}$ & MPN/100 mL & $\begin{array}{c}4.6 \times 10^{2} ; 2.7 \log \\
(\downarrow 95.8)\end{array}$ & $\begin{array}{c}4.6 \times 10^{3} ; 3.7 \log \\
(\downarrow 58.2)\end{array}$ & $\begin{array}{c}4.6 \times 10^{3} ; 3.7 \log \\
(\downarrow 58.2)\end{array}$ \\
\hline $\begin{array}{c}\text { Total Proteolytic Count, } \\
\text { TPC }\end{array}$ & $\mathrm{CFU} / \mathrm{mL}$ & $\begin{array}{c}1.9 \times 10^{2} ; 2.3 \log \\
(\downarrow 99.3)\end{array}$ & $\begin{array}{c}2.4 \times 10^{3} ; 3.4 \log \\
(\downarrow 90.8)\end{array}$ & $\begin{array}{c}2.6 \times 10^{3} ; 3.4 \log \\
(\downarrow 90.0)\end{array}$ \\
\hline \multicolumn{5}{|c|}{ 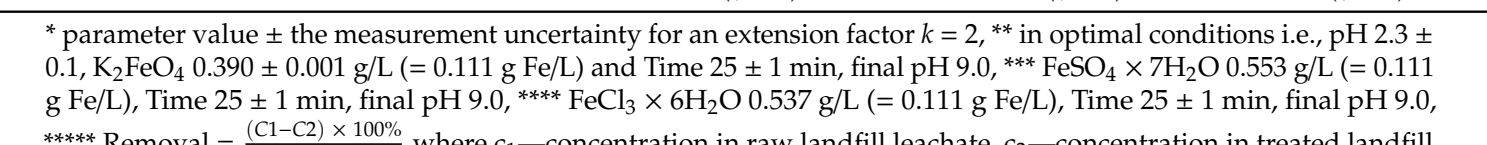 } \\
\hline
\end{tabular}

\subsection{Coagulation/Flocculation Findings and $\mathrm{K}_{2} \mathrm{FeO}_{4}$ Biocidal Properties}

Table 6 reports the findings of tests of purified leachates after the application of $\mathrm{K}_{2} \mathrm{FeO}_{4}$ (under optimal conditions) and $\mathrm{FeSO}_{4} \times 7 \mathrm{H}_{2} \mathrm{O}$ and $\mathrm{FeCl}_{3} \times 6 \mathrm{H}_{2} \mathrm{O}$ in an amount equivalent to the dose of iron contained in $0.390 \mathrm{~g}$ of $\mathrm{K}_{2} \mathrm{FeO}_{4}$.

The test results revealed that the use of an equivalent dose of iron in the form of $\mathrm{FeSO}_{4} \times 7 \mathrm{H}_{2} \mathrm{O}$ and $\mathrm{FeCl}_{3} \times 6 \mathrm{H}_{2} \mathrm{O}$ made it possible to reduce the COD, TOC, TN values only by $38.1 \%, 37.0 \%, 20.8 \%$ (in the case of $\mathrm{FeSO}_{4} \times 7 \mathrm{H}_{2} \mathrm{O}$ ) and $41.6 \%, 45.7 \%$, and $29.2 \%$ (in the case of $\left(\mathrm{FeCl}_{3} \times 6 \mathrm{H}_{2} \mathrm{O}\right.$ ), compared to $\mathrm{K}_{2} \mathrm{FeO}_{4}$, the application of which was much more effective (see Table 6, column 3). Additionally, in all cases a reduction of the TP value $>90 \%$ was achieved. It is clear that the removal of impurities from the tested leachates was not only due to coagulation, co-precipitation and adsorption (as in the case with conventional coagulants), but also as a result of oxidation process using $\mathrm{K}_{2} \mathrm{FeO}_{4}$. Additionally, it should be noted that in the case of using conventional coagulants, the efficiency of removing microorganisms was comparable and amounted to $92.1 \%, 58.2 \%, 90.0 \%$ (in the case $\mathrm{FeCl}_{3} \times 6 \mathrm{H}_{2} \mathrm{O}$ for TCC, MPN, TPC) and $94.4 \%, 58.2 \%, 90.8 \%$ (in the case $\mathrm{FeSO}_{4} \times 7 \mathrm{H}_{2} \mathrm{O}$ for TCC, MPN, TPC), respectively. When $\mathrm{K}_{2} \mathrm{FeO}_{4}$ was used the microorganism removal efficiency was $99.9 \%, 95.8 \%$ and $99.3 \%$ for TCC, MPN and TPC, respectively.

The obtained results indicate an additional biocidal effect related to the oxidizing properties of the $\mathrm{FeO}_{4}{ }^{2-}$ ion in an acidic environment. Other studies revealed that $\mathrm{K}_{2} \mathrm{FeO}_{4}$ can reach the disinfection targets ( $>6 \log$ inactivation of Escherichia coli) at a very low dose $(6 \mathrm{mg} / \mathrm{L}$ as $\mathrm{Fe})$ and over wide working $\mathrm{pH}$ range compared to chlorination $\left(10 \mathrm{mg} / \mathrm{L}\right.$ as $\left.\mathrm{Cl}_{2}\right)$ and coagulation $\left(\mathrm{Fe}_{2}\left(\mathrm{SO}_{4}\right)_{3} 3.4 \mathrm{mg} / \mathrm{L}\right.$ as $\mathrm{Fe}$ ). In wastewater treatment, $\mathrm{K}_{2} \mathrm{FeO}_{4}$ kill $3 \mathrm{log}$ more bacteria in comparison with $\mathrm{Al}_{2}\left(\mathrm{SO}_{4}\right)_{3}$ and $\mathrm{Fe}_{2}\left(\mathrm{SO}_{4}\right)_{3}$ at a similar or even smaller dose [64]. Reports have shown that ferrate (VI) has excellent disinfectant properties and can inactivate a wide variety of microorganisms at low ferrate (VI) dosages. Additionally, ferrate (VI) can disable many chlorine-resistant organisms, such as aerobic spore-formers and sulphite-reducing Clostridia. The ferrate (VI) can deactivate not only Escherichia coli at lower dosages or shorter contact time than hypochlorite, but also Bacillus cereus, Streptococcus bovis, Staphylococcus aureus, Shigella flexneri, Streptococcus faecalis and Salmonella typhimurium, respectively. In turn, ferrate (V) has been proven to be highly reactive and about $10^{3}-10^{5}$ times more reactive to impurities than ferrate (VI), suggesting that the eradication of toxins by ferrate (VI) may be enhanced in the presence of appropriate one-electron-reducing agents. The ferrate $(\mathrm{V})$ has the capability of inactivating biological species and toxins, which cannot be reached by ferrate (VI) [65]. Since the high reactivity of ferrate (V) 
allows to inactivate biological species and toxins which cannot be eliminated by ferrate (VI), it seems that this property may also be responsible for inactivation of bacteria.

Moreover, recent investigations suggested that iron sludge containing iron (III) salts and hydroxides that left after the treatment of leachate may be reused for manufacturing of ferrate (VI) [66]. This possibility of reusing sludge after treatment fits very well to the concept of a circular economy. From the practical and technological point of view, it is important to be able to generate ferrate (VI) in situ [67], which reduces the costs of synthesis, transport, storage and handling.

\section{Conclusions}

The use of potassium ferrate (VI) for the treatment of leachate from a municipal landfill site made it possible to obtain clean leachate characterized by low values of physicochemical (COD, TOC, TN, TP) and microbiological (TCC, MPN, TPC) parameters. Under optimal conditions, potassium ferrate (VI) effectively decomposed organic compounds present in the leachate and inactivated microorganisms, which was related to its disinfecting effect. The use of conventional coagulants in the form of iron (II) and (III) salts allowed for only partial removal of impurities from the tested leachate. Both in the case of potassium ferrate (VI) and conventional coagulants, iron (II) and (III) hydroxides are formed, which can adsorb impurities or lead to their co-precipitation. The maximum efficiency of pollutant removal was obtained with the use of $\mathrm{K}_{2} \mathrm{FeO}_{4}$ in the process of their oxidation, and then coagulation, adsorption and co-precipitation. Moreover, iron sludge left after the treatment of leachate may be reused for generation of ferrate. Thus, $\mathrm{K}_{2} \mathrm{FeO}_{4}$ can be treated as an effective, multi-functional and environmentally-friendly coagulant for the treatment of leachate from municipal landfills.

Author Contributions: Conceptualization, M.T.; methodology, M.T., A.B., K.B., V.K.; statistical analysis, M.T.; formal analysis, M.T.; data curation, M.T.; writing-original draft preparation, M.T.; writing—review and editing, M.T., V.K., A.S., K.B., A.B.; visualization, M.T.; supervision, K.B. and J.J.; project administration, V.K. and A.B.; funding acquisition, V.K., A.B. and J.J. All authors have read and agreed to the published version of the manuscript.

Funding: This work was supported by Ministry of Science and Higher Education Republic of Poland within statutory funds. This work was also supported by the Slovak Research and Development Agency (APVV-17-0373, APVV-17-0318) and the Slovak Grant Agency for Science (VEGA 1/0787/18).

Acknowledgments: The authors would like to thank the anonymous reviewers for their helpful comments.

Conflicts of Interest: The authors declare no conflict of interest.

\section{References}

1. Dlugosz, J. Characteristics of the composition and quantity of leachate from municipal landfills-A review. Arch. Waste Manag. Environ. Prot. 2012, 14, 19-30.

2. Xaypanya, P.; Takemura, J.; Chiemchaisri, C.; Hul, S.; Tanchuling, M.A.N. Characterization of Landfill Leachates and Sediments in Major Cities of Indochina Peninsular Countries-Heavy Metal Partitioning in Municipal Solid Waste Leachate. Environment 2018, 5, 65. [CrossRef]

3. Banel, A.; Zygmunt, B. Volatile fatty acids in a landfill—occurrence and determination. Ecol. Chem. Eng. S. 2009, 16, 193-206.

4. Renou, S.; Givaudan, J.; Poulain, S.; Dirassouyan, F.; Moulin, P. Landfill leachate treatment: Review and opportunity. J. Hazard. Mater. 2008, 150, 468-493. [CrossRef] [PubMed]

5. Urase, T.; Kikuta, T. Separate estimation of adsorption and degradation of pharmaceutical substances and estrogens in the activated sludge process. Water Res. 2005, 39, 1289-1300. [CrossRef] [PubMed]

6. Poznyak, T.; Bautista, G.L.; Chairez, I.; Córdova, R.I.; Ríos, L.E. Decomposition of toxic pollutants in landfill leachate by ozone after coagulation treatment. J. Hazard. Mater. 2008, 152, 1108-1114. [CrossRef] [PubMed]

7. Kabdaşlı, I.; Şafak, A.; Tünay, O. Bench-scale evaluation of treatment schemes incorporating struvite precipitation for young landfill leachate. Waste Manag. 2008, 28, 2386-2392. [CrossRef] [PubMed]

8. François, V.; Feuillade-Cathalifaud, G.; Skhiri, N.; Lagier, T.; Matejka, G. Indicating the parameters of the state of degradation of municipal solid waste. J. Hazard. Mater. 2006, 137, 1008-1015. [CrossRef]

9. Öman, C.; Junestedt, C. Chemical characterization of landfill leachates-400 parameters and compounds. Waste Manag. 2008, 28, 1876-1891. [CrossRef] 
10. Budi, S.; Suliasih, B.A.; Othman, M.S.; Heng, L.Y.; Surif, S. Toxicity identification evaluation of landfill leachate using fish, prawn and seed plant. Waste Manag. 2016, 55, 231-237. [CrossRef]

11. Bis, M.; Montusiewicz, A.; Ozonek, J.; Pasieczna-Patkowska, S. Application of hydrodynamic cavitation to improve the biodegradability of mature landfill leachate. Ultrason. Sonochem. 2015, 26, 378-387. [CrossRef]

12. Civan, F.; Özaltun, D.H.; Kıpçak, E.; Akgün, M. The treatment of landfill leachate over Ni/Al2O3 by supercritical water oxidation. J. Supercrit. Fluids 2015, 100, 7-14. [CrossRef]

13. Theepharaksapan, S.; Chiemchaisri, C.; Chiemchaisri, W.; Yamamoto, K. Removal of pollutants and reduction of bio-toxicity in a full scale chemical coagulation and reverse osmosis leachate treatment system. Bioresour. Technol. 2011, 102, 5381-5388. [CrossRef]

14. Mnif, S.; Zayen, A.; Karray, F.; Bru-Adan, V.; Loukil, S.; Godon, J.J.; Chamkha, M.; Sayadi, S. Microbial population changes in anaerobic membrane bioreactor treating landfill leachate monitored by single-strand conformation polymorphism analysis of 16S rDNA gene fragments. Int. Biodeterior. Biodegrad. 2012, 73, 50-59. [CrossRef]

15. Li, X.; Song, J.; Guo, J.; Wang, Z.; Feng, Q. Landfill leachate treatment using electrocoagulation. Procedia Environ. Sci. 2011, 10, 1159-1164. [CrossRef]

16. Zhao, X.; Qu, J.; Liu, H.; Wang, C.; Xiao, S.; Liu, R.; Liu, P.; Lan, H.; Hu, C. Photoelectrochemical treatment of landfill leachate in a continuous flow reactor. Bioresour. Technol. 2010, 101, 865-869. [CrossRef] [PubMed]

17. Deng, Y.; Englehardt, J.D. Electrochemical oxidation for landfill leachate treatment. Waste Manag. 2007, 27, 380-388. [CrossRef] [PubMed]

18. Bu, L.; Wang, K.; Zhao, Q.; Wei, L.-L.; Zhang, J.; Yang, J.-C. Characterization of dissolved organic matter during landfill leachate treatment by sequencing batch reactor, aeration corrosive cell-Fenton, and granular activated carbon in series. J. Hazard. Mater. 2010, 179, 1096-1105. [CrossRef]

19. Ben Yahmed, A.; Saidi, N.; Trabelsi, I.; Murano, F.; Dhaifallah, T.; Bousselmi, L.; Ghrabi, A. Microbial characterization during aerobic biological treatment of landfill leachate (Tunisia). Desalination 2009, 246, 378-388. [CrossRef]

20. Mariam, T.; Guo, W. Landfill leachate treatment using hybrid coagulation-nanofiltration processes. Desalination 2010, 250, 677-681. [CrossRef]

21. Cortez, S.; Teixeira, P.; Oliveira, R.; Mota, M. Ozonation as polishing treatment of mature landfill leachate. J. Hazard. Mater. 2010, 182, 730-734. [CrossRef] [PubMed]

22. Mojiri, A.; Ziyang, L.; Tajuddin, R.M.; Farraji, H.; Alifar, N. Co-treatment of landfill leachate and municipal wastewater using the ZELIAC/zeolite constructed wetland system. J. Environ. Manag. 2016, 166, 124-130. [CrossRef] [PubMed]

23. Hu, L.; Niu, C.-G.; Chen, G.; Dong, H.; Liu, Y.; Wan, J.; Chen, A.; Guo, Z.; Yan, M.; Wu, H.; et al. Treatment of landfill leachate using immobilized Phanerochaete chrysosporium loaded with nitrogen-doped TiO 2 nanoparticles. J. Hazard. Mater. 2016, 301, 106-118. [CrossRef] [PubMed]

24. Ziyang, L.; Zhao, Y.; Tao, Y.; Yu, S.; Huili, C.; Nanwen, Z.; Renhua, H. Natural attenuation and characterization of contaminants composition in landfill leachate under different disposing ages. Sci. Total. Environ. 2009, 407, 3385-3391. [CrossRef]

25. Oz, N.A.; Yarimtepe, C.C. Ultrasound assisted biogas production from landfill leachate. Waste Manag. 2014, 34, 1165-1170. [CrossRef]

26. Wu, L.; Peng, C.; Zhang, S.; Peng, Y. Nitrogen removal via nitrite from municipal landfill leachate. J. Environ. Sci. 2009, 21, 1480-1485. [CrossRef]

27. Kargi, F.; Catalkaya, E.C. Electrohydrolysis of landfill leachate organics for hydrogen gas production and COD removal. Int. J. Hydrog. Energy 2011, 36, 8252-8260. [CrossRef]

28. Tsarpali, V.; Dailianis, S. Investigation of landfill leachate toxic potency: An integrated approach with the use of stress indices in tissues of mussels. Aquat. Toxicol. 2012, 58-65. [CrossRef]

29. Isaka, K.; Yoshie, S.; Sumino, T.; Inamori, Y.; Tsuneda, S. Nitrification of landfill leachate using immobilized nitrifying bacteria at low temperatures. Biochem. Eng. J. 2007, 37, 49-55. [CrossRef]

30. Tatsi, A.; Zouboulis, A.; Matis, K.; Samaras, P. Coagulation-flocculation pretreatment of sanitary landfill leachates. Chemosphere 2003, 53, 737-744. [CrossRef]

31. Jones, D.; Williamson, K.; Owen, A. Phytoremediation of landfill leachate. Waste Manag. 2006, 26, 825-837. [CrossRef] 
32. Lema, J.M.; Mendez, R.; Blazquez, R. Characteristics of landfill leachates and alternatives for their treatment: A review. Water Air Soil Pollut. 1988, 40, 223-250.

33. Tatsi, A.; Zouboulis, A.I. A field investigation of the quantity and quality of leachate from a municipal solid waste landfill in a Mediterranean climate (Thessaloniki, Greece). Adv. Environ. Res. 2002, 6, 207-219. [CrossRef]

34. Salem, Z.; Hamouri, K.; Djemaa, R.; Allia, K. Evaluation of landfill leachate pollution and treatment. Desalination 2008, 220, 108-114. [CrossRef]

35. Pieczykolan, B.; Płonka, I.; Barbusiński, K.; Amalio-Kosel, M. Comparison of Landfill Leachate Treatment Efficiency Using the Advanced Oxidation Processes. Arch. Environ. Prot. 2013, 39, 107-115. [CrossRef]

36. Barbusiński, K.; Pieczykolan, B. COD removal from landfill leachate using Fenton oxidation and coagulation. Archit. Civ. Eng. Environ. 2010, 4, 93-100.

37. Pieczykolan, K.B.B. COD removal from landfill leachate using $\mathrm{H} 2 \mathrm{O} 2$, UV radiation and combination these processes. Environ. Prot. Eng. 2012, 38, 5-12. [CrossRef]

38. Pieczykolan, B.; Barbusiński, K.; Płonka, I. Effect of landfill leachate on the biological treatment of wastewater. Przem. Chem. 2011, 90, 1555-1559.

39. Barbusiński, K.; Pieczykolan, B.; Kościelniak, H.; Amalio, M. Effect of landfill leachate on the efficiency of municipal sewage treatment and on the properties of activated sludge. Ochrona Srodowiska 2010, 32, 33-38.

40. Kulikowska, D. Characterization of organics and methods treatment of leachate from stabilized municipal landfills. Ecol. Chem. Eng. S. 2009, 16, 389-402.

41. Paxéus, N. Organic compounds in municipal landfill leachates. Water Sci. Technol. 2000, 42, $323-333$. [CrossRef]

42. Sharma, V.K. Potassium ferrate (VI): An environmentally friendly oxidant. Adv. Environ. Res. 2002, 6, 143-156. [CrossRef]

43. Kliś, S.; Barbusiński, K.; Thomas, M.; Mochnacka, A. Application of potassium ferrate (VI) in the treatment of selected water and wastewater pollutants-Short review. Arch. Civ. Eng. Environ. 2020, 13, 129-138. [CrossRef]

44. Kliś, S.; Barbusiński, K.; Thomas, M.; Mochnacka, A. Application of potassium ferrate (VI) for oxidation of selected pollutants in aquatic environment-Short review. Arch. Civ. Eng. Environ. 2019, 12, 129-137. [CrossRef]

45. Thomas, M.; Zdebik, D. Treatment of Real Textile Wastewater by Using Potassium Ferrate (VI) and Fe (III)/H2O2. Application of Aliivibrio Fischeri and Brachionus plicatilis Tests for Toxicity Assessment. Fibres Text. East. Eur. 2019, 27, 78-84. [CrossRef]

46. Thomas, M.; Barbusinski, K.; Kliś, S.; Szpyrka, E.; Chyc, M. Synthetic Textile Wastewater Treatment using Potassium Ferrate (VI)_Application of Taguchi Method for Optimisation of Experiment. Fibres Text. East. Eur. 2018, 26, 104-109. [CrossRef]

47. Schreyer, J.M.; Thompson, G.W.; Ockerman, L.T. Oxidation of Chromium (III) with Potassium Ferrate (VI). Anal. Chem. 1950, 22, 1426-1427. [CrossRef]

48. Wei, Y.-L.; Wang, Y.-S.; Liu, C.-H. Preparation of Potassium Ferrate from Spent Steel Pickling Liquid. Metals 2015, 5, 1770. [CrossRef]

49. ISO. 10523:2008 Water Quality. Determination of pH. Available online: https://www.iso.org/standard/51994. html (accessed on 5 October 2020).

50. ISO. 15705:2002 Water Quality. Determination of the Chemical Oxygen Demand Index (ST-COD). Small-Scale Sealed-Tube Method. Available online: https://www.iso.org/standard/28778.html (accessed on 5 October 2020).

51. Test 985094. TOC 60. Macherey-Nagel GmbH \& Co. KG 5, Düren, German. Available online: http: //ftp.mn-net.com/english/Instruction_leaflets/NANOCOLOR/985094en.PDF (accessed on 10 August 2020).

52. Test 985088. Total Nitrogen TNb 220. Macherey-Nagel GmbH \& Co. KG 5, Düren, Germany. Available online: https://www.mn-net.com/media/pdf/1a/bf/a1/Instruction-985088-Tube-test-NANOCOLOR-totalNitrogen-TNb-220.PDF (accessed on 10 August 2020).

53. Test 985080. Ortho- and Total Phosphat 15. Macherey-Nagel GmbH \& Co. KG 5, Düren, Germany. Available online: https://www.mn-net.com/media/pdf/a8/a4/4c/Instruction-985080-Tube-test-NANOCOLOR-orthoand-total-Phosphate-15.PDF (accessed on 10 August 2020). 
54. ISO 6887-1:2017. Microbiology of the Food Chain-Preparation of Test Samples, Initial Suspension and Decimal Dilutions for Microbiological Examination-Part 1: General Rules for the Preparation of the Initial Suspension and Decimal Dilutions. Available online: https://www.iso.org/standard/63335.html (accessed on 5 October 2020).

55. ISO 4832:2006. Microbiology of Food and Animal Feeding Stuffs-Horizontal Method for the Enumeration of Coliforms-Colony-Count Technique. Available online: https://www.iso.org/standard/38282.html (accessed on 5 October 2020).

56. PN-75/C-04615/17:1975 Microbiological Tests. Determination of Proteolytic Bacteria by Frazier's Method; The Polish Committee for Standardization: Warsaw, Poland, 1975.

57. PN-C-04615-25:2008 Water and Wastewater. Microbiological Tests. Part 25. Determination of Fecal Enterococci by Tube Test; The Polish Committee for Standardization: Warsaw, Poland, 2008.

58. Grisey, E.; Belle, E.; Dat, J.; Mudry, J.; Aleya, L. Survival of pathogenic and indicator organisms in groundwater and landfill leachate through coupling bacterial enumeration with tracer tests. Desalination 2010, 261, 162-168. [CrossRef]

59. Kozik, V.; Barbusinski, K.; Thomas, M.; Sroda, A.; Jampilek, J.; Sochanik, A.; Smolinski, A.; Bak, A. Taguchi Method and Response Surface Methodology in the Treatment of Highly Contaminated Tannery Wastewater Using Commercial Potassium Ferrate. Materials 2019, 12, 3784. [CrossRef]

60. Thomas, M.; Barbusinski, K.; Kalemba, K.; Piskorz, P.J.; Kozik, V.; Bak, A. Optimization of the Fenton Oxidation of Synthetic Textile Wastewater using Response Surface Methodology. Fibres Text. East. Eur. 2017, 25, 108-113. [CrossRef]

61. Aslani, H.; Nabizadeh, R.; Nasseri, S.; Mesdaghinia, A.; Alimohammadi, M.; Mahvi, A.H.; Rastkari, N.; Nazmara, S. Application of response surface methodology for modeling and optimization of trichloroacetic acid and turbidity removal using potassium ferrate (VI). Desalin. Water Treat. 2016, 57, 25317-25328. [CrossRef]

62. Lan, S.; Liu, X.; Chen, R.; Wan, Y.; Wu, X.; Zhang, H. Study on pretreatment of landfill leachate by potassium ferrate. Desalin. Water Treat. 2013, 52, 2757-2764. [CrossRef]

63. Zhang, Y.; Luo, Z.; Qu, Y.; Lin, Y.; Huang, D.; Zheng, Z. Pretreatment of landfill leachate by potassium ferrate (VI). Chin. J. Environ. Eng. 2014, 8, 2451-2455.

64. Jiang, J.-Q.; Wang, S.; Panagoulopoulos, A. The exploration of potassium ferrate (VI) as a disinfectant/coagulant in water and wastewater treatment. Chemosphere 2006, 63, 212-219. [CrossRef]

65. Sharma, V.K. Desinfection performance of Fe (VI) in water and wastewater: A review. Water Sci. Technol. 2007, 55, 225-232. [CrossRef]

66. Sánchez-Carretero, A.; Sáez, C.; Cañizares, P.; Cotillas, S.; Rodrigo, M.A. Improvements in the Electrochemical Production of Ferrates with Conductive Diamond Anodes Using Goethite as Raw Material and Ultrasound. Ind. Eng. Chem. Res. 2011, 50, 7073-7076. [CrossRef]

67. Ghernaout, D.; Naceur, M.W. Ferrate (VI): In situ generation and water treatment-A review. Desalin. Water Treat. 2011, 30, 319-332. [CrossRef]

Publisher's Note: MDPI stays neutral with regard to jurisdictional claims in published maps and institutional affiliations.

(C) 2020 by the authors. Licensee MDPI, Basel, Switzerland. This article is an open access article distributed under the terms and conditions of the Creative Commons Attribution (CC BY) license (http://creativecommons.org/licenses/by/4.0/). 